\title{
Case Report on Intravenous Ranitidine Induced Anaphylactic Reaction in Cholangiocarcinoma Patient
}

\author{
Khayati Moudgil', Sivasankaran Ponnusankar ${ }^{2 *}$ \\ ${ }^{1}$ Department of Pharmacy Practice, JSS College of Pharmacy, Udhagamandalam- 643001, The Nilgiris, Tamil Nadu, INDIA. \\ 2JSS Academy of Higher Education and Research, Mysuru, Karnataka, INDIA.
}

\begin{abstract}
Ranitidine hydrochloride being one of the most commonly used drugs and its use is well provident. Furthermore, anaphylactic reactions are rarely observed with the use of ranitidine hydrochloride. Hypersensitivity reactions are usually common in clinical practice but adverse reaction to intravenous ranitidine is very rare. Here we report a case, where the patient developed an anaphylactic reaction with a single dose of intravenous ranitidine in cholangiocarcinoma patient. This report highlights the importance of recognition of the serious adverse events that might follow and the need for cautiousness with the use of ranitidine in the future prospects.
\end{abstract}

Key words: Adverse drug reaction, Flare, Histamine, Ranitidine, Itching, Wheal.

\section{INTRODUCTION}

Ranitidine is a competitive, reversible inhibitor of $\mathrm{h}_{2}$-receptors, prominently including the receptors on the gastric cells ${ }^{1}$ thus characterized as Histamine $\mathrm{H}_{2}$-receptor antagonists, also known as $\mathrm{H}_{2}$ blockers. Widely used over-the-counter (OTC), these medicines are used to relieve and/or prevent heartburn, acid indigestion, and sour stomach, and also as in prescription therapy for duodenal ulcers and in gastritis as a surface protectant. $\mathrm{H}_{2}$-blockers work by decreasing the amount of acid produced by the stomach. ${ }^{2}$

The term wheal and flare reaction signifies a skin eruption that may follow injury or injection of an antigen, ${ }^{2}$ characterized by swelling and redness caused by the release of histamine. The reaction usually occurs in three stages, beginning with the appearance of an erythematous area at the site of injury, followed by development of a flare surrounding the site and finally formation of wheals at the site as a result of fluid leakage under the skin from the surrounding capillaries. The incidence of wheal and flare reaction to ranitidine hydrochloride has been reported in all age groups. ${ }^{3}$

\section{CASE REPORT}

A 67-year-old male was admitted in the intensive care unit of the public secondary care hospital, Udhagamandalam with complaints of hematemesis, abdominal pain, abdominal discomfort, swelling of both legs (peripheral edema), loss of appetite and jaundice and pain in the right shoulder.

The patient is a known case of cholangiocarcinoma with Liver and Spine Metastases. His CT Abdomen and Pelvis shows following:

- Large mass lesion involving segment II, III and IV of liver showing peripheral arterial enhancement with central progression in venous phase with delayed enhancement.

- Capsular retraction and left lobe atrophy.

- Minimal Intra hepatic biliary radicles dilatation.

- Invasion of left and middle hepatic veins.
DOI: 10.5530/ijopp.10.4.64

Address for correspondence: Dr. Sivasankaran Ponnusankar,

Professor and Head Department of Pharmacy Practice, JSS College of Pharmacy, Udhagamandalam-643 001, The Niligirs. Tamil Nadu, INDIA. Phone no: +91-9489613428 Email Id: ponnusankarsivas\#@ gmail.com

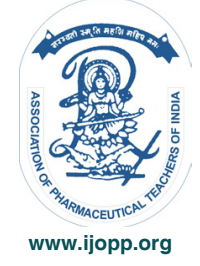


- Multiple Intra hepatic metastatic lesions.

- Few enlarged lymph nodes in helium.

- Gall bladder and bowel appear normal.

- No metastatic lesion in bone or visualised portion of lung.

Features suggested of intrahepatic cholangiocarcinoma with multiple hepatic metastasis.

- Porto- systemic collaterals are seen around rectum.

The patient is on chemotherapy with Cap. Capecitabine $500 \mathrm{mg}$. Patient is a known case of systemic hypertension and ischemic heart disease. His clinical investigations are suggestive of moderate aortic regurgitation with adequate LV systolic function. He is on treatment with Tab. Atenolol 25mg OD, Tab. Enalapril maleate $2.5 \mathrm{mg}$ BD, Tab. Isosorbide dinitrate $5 \mathrm{mg}$ BD. Patient had a history of Right Direct Inguinal Hernia for which hernioplasty was performed respectively.

His previous reports included:

Right Direct Inguinal Hernia, After Cardiac fitness assessment under SA, Right Inguinal Hernioplasty done with prolene mesh.

Post-OP: Post OP period uneventful. Tolerated normal diet.

In-patient Medications:

Tablet Enalapril maleate $2.5 \mathrm{mg}$ (Envas); Tablet Atenolol $50 \mathrm{mg}$ (Acard); Injection Diclofenac $75 \mathrm{mg}$ (Dynapar AQ); Capsule Domperidone $30 \mathrm{mg}+$ Capsule Rabeprazole 20 mg (Rabesec D); Tablet Trypsin 48mg + Bromelain $100 \mathrm{mg}+$ Rutoside $90 \mathrm{mg}+$ Diclofenac $50 \mathrm{mg}$ (Rutoheal D); Tablet Digoxin $0.25 \mathrm{mg}$ (Lanoxin).

At the time of admission, his CT Chest (Plain/Contrast) was done which showed following:

- Azygous fissure noted

- Fibrotic strands in Rt ML

- Erosion of posterior aspect of Lt $2^{\text {nd }}$ rib and Lt Transverse of D2 with enhancing soft tissue component. Lytic area also seen in D8

- Old fracture posterior aspect of Lt. $11^{\text {th }}$ rib
- Multiple hypodense lesions nodules in both lobes of liver

- Granulomatous calcifications in Lt. Lobe of liver

On examination, he was found to be conscious, oriented and afebrile. Pulse rate was 88 beats/min, blood pressure: $90 / 70 \mathrm{mmHg}$, oxygen saturation of $95 \%$ by pulse oximetry, whereas $\mathrm{P} / \mathrm{A}$ shows the presence of hepatomegaly and ascites. Table 1 shows the laboratory data of the patient at the time of administration.

The Patient underwent trucut biopsy of liver and the results shows that multiple sections of tiny clusters of malignant epithelial cells with hyperchromatic nuclear cytoplasmic ratio forming tiny acini in a dense stroma, metastatic adenocarcinomatous deposits and cholangiocarcinoma.

The patient was prescribed with intravenous Ranitidine $50 \mathrm{mg}$ bid, Injection Tramadol 100mg IV bid, Injection Vitamin K $10 \mathrm{mg} / \mathrm{ml}$ IM OD. Within min of the administration of injection ranitidine, the patient developed manifestations of itching, wheal and flare reaction on his forearm (Figure 1). After which, Ranitidine was stopped immediately and Tab. Cetirizine $5 \mathrm{mg}$ was prescribed to the patient.

Based on the above findings, he was diagnosed as a case exhibiting an adverse drug reaction due to intravenous ranitidine. Injection was stopped immediately and his vitals were normalised after stopping injection Ranitidine. On the next day poor prognosis of the patient was explained to the patient and his caretaker. Due to the poor prognosis, the patient was later referred to tertiary care hospital for further management. The event was

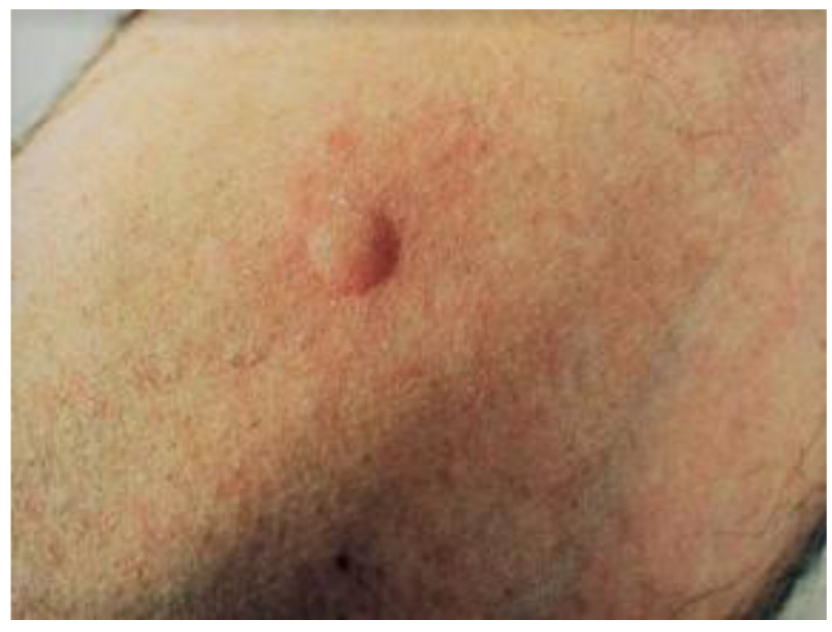

Figure 1: The reaction of IV Ranitidine at single dose.

The Wheal and Flare reaction (Angioedema and Urticaria) is seen in the Figure 


\begin{tabular}{|c|c|c|c|}
\hline Parameters & \multicolumn{2}{|c|}{ Laboratory values } & Reference range \\
\hline Haemoglobin & \multicolumn{2}{|c|}{$10.5 \mathrm{~g} / \mathrm{dl}$} & $14 \mathrm{~g} / \mathrm{dL}-18 \mathrm{~g} / \mathrm{dL}$ \\
\hline Total count & \multicolumn{2}{|c|}{$13.7 \times 10^{3} \mathrm{cells} / \mathrm{mm}^{3}$} & $3.2-9.8 \times 10^{3} \mathrm{cells} / \mathrm{mm}^{3}$ \\
\hline Red blood cells & \multicolumn{2}{|c|}{$2.78 \times 10^{6} / \mathrm{mm}^{3}$} & $4.3-5.9 \times 10^{3} \mathrm{cells} / \mathrm{mm}^{3}$ \\
\hline Random blood sugar & \multicolumn{2}{|c|}{$57 \mathrm{mg} / \mathrm{dl}$} & $<200 \mathrm{mg} / \mathrm{dL}$ \\
\hline Potassium & \multicolumn{2}{|c|}{$5.27 \mathrm{mEq} / \mathrm{L}$} & $3.5-5 \mathrm{mEq} / \mathrm{L}$ \\
\hline Blood urea & \multicolumn{2}{|c|}{$91 \mathrm{mg} / \mathrm{dL}$} & $20-40 \mathrm{mg} / \mathrm{dL}$ \\
\hline Serum Creatinine & \multicolumn{2}{|c|}{$1.8 \mathrm{mg} / \mathrm{dL}$} & $0.6-1.2 \mathrm{mg} / \mathrm{dL}$ \\
\hline AST & \multicolumn{2}{|c|}{$53 \mathrm{U} / \mathrm{L}$} & $0-35 U / L$ \\
\hline ALT & \multicolumn{2}{|c|}{$0.5 \mathrm{U} / \mathrm{L}$} & $0-35 \mathrm{U} / \mathrm{L}$ \\
\hline ALP & \multicolumn{2}{|c|}{$201 \mathrm{U} / \mathrm{L}$} & $30-120 U / L$ \\
\hline \multirow[t]{3}{*}{ Bilirubin } & Total & $2.5 \mathrm{mg} / \mathrm{dL}$ & $0.1-1 \mathrm{mg} / \mathrm{dL}$ \\
\hline & Direct & $1.9 \mathrm{mg} / \mathrm{dL}$ & $0-0.2 \mathrm{mg} / \mathrm{dL}$ \\
\hline & Indirect & $1.2 \mathrm{mg} / \mathrm{dL}$ & $0.1-0.8 \mathrm{mg} / \mathrm{dL}$ \\
\hline Urine albumin & \multicolumn{2}{|c|}{ Trace } & \\
\hline Deposits & \multicolumn{2}{|c|}{-} & \\
\hline Granular cyst & \multicolumn{2}{|c|}{+} & \\
\hline
\end{tabular}

2-D Electrocardiogram/ M-Mode and Doppler suggested moderate aortic regurgitation, AR Vmax $=3.8 \mathrm{~m} / \mathrm{s}$, asymmetrical left ventricular hypertrophy.

categorized as a probable event using the Naranjo's probability scale for the relationship between the drug and the adverse reaction.

\section{DISCUSSION}

Ranitidine is one of the most widely used drug and is considered rationally safe by most of the prescribers and the consumers. Highly attributing to its low incidence of adverse reactions. ${ }^{4}$ Histamine plays an important role as a mediator of allergic reactions. It is stored in the granules of mast cells and basophils and is released not only when an allergen cross-links surface bound $\operatorname{IgE}$, but also mediated by the complement system and other chemical or physical stimuli. ${ }^{5}$

Ranitidine was introduced in 1981 and was the world's biggest-selling prescription by 1987 . It has since largely been superseded by the even more effective protonpump inhibitors, with omeprazole becoming the biggestselling drug for many years. Anaphylaxis is rarely seen with ranitidine. ${ }^{6}$ A wide array of ranitidine-associated side effects has been reported but infrequently. ${ }^{7} \mathrm{H}_{2}$ receptor antagonists are commonly used and prescribed medications and generally known to be well tolerated. ${ }^{8}$

Literature reveals that this rare drug reaction occurs mostly with intravenous Ranitidine. The only way to prevent such type of adverse reaction is to evade the drugs for which the patient is found to be allergic. ${ }^{9}$ The use of drug allergy card plays an important role for the safer design of a patient's therapy planning. Hypersensitivity to specific drugs by means of drug allergy card or by an electronic media ${ }^{10}$ can contribute as a preventive measure. By such means, simultaneously the pharmacists can educate the patients and patient's relatives about anaphylactic reactions and their consequences to the overall wellbeing of the patient. A skin prick test with ranitidine is a good measure that requires more importance and more light in the present scenario of such circumstances. ${ }^{11,12}$

As a whole, though it has been considered safe notably because of the fewer reports of adverse effects. However, the need still arises with the high incidence of its use and the possibility of adverse reactions in some patients that might lead to critical conditions.

\section{CONCLUSION}

Ranitidine is most commonly used in the treatment for gastric ulcer and gastroesophageal reflux diseases. The incidence rate of adverse reactions associated with Ranitidine has been low, probably due to the less number of such events and such that cases may also be under reported. This case report emphasizes the need of caution and the probability that such events might follow with the use of Ranitidine. Furthermore, the need of reporting of such events to implement monitoring strategies and management approaches in the near future. Hypersensitivity drug reactions can be life-threatening, prolong hospital stay and hence further results in socioeconomic costs. 


\section{ACKNOWLEDGMENT}

The authors acknowledge the support and cooperation provided by the Government headquarters hospital, Udhagamandalam, Tamil Nadu.

\section{CONFLICT OF INTEREST}

The authors declare no conflict of interest.

\section{ABBREVIATION USED}

IV: Intravenous; IM: Intramuscular; BD: Twice daily; IgE: Immunoglobulin E; AST: Aspartate aminotransferase; ALT: Alanine aminotransferase; ALP: Alkaline phosphatase.

\section{REFERENCES}

1. Micromedex - Drug Information, Histamine H2 antagonist, Drugs and Suppliments, Mayo Clinic. Available from: https://www.mayoclinic.org/drugssupplements/histamine-h2-antagonist-oral-route-injection-route-intravenousroute/description/drg-20068584.
2. Meyrick-Thomas RH, Browne PD, Kirby JD. The effect of ranitidine, alone and in combination with clemastine, on allergen-induced cutaneous wheal-and-flare reactions in human skin. J Allergy ClinImmunol. 1985;76(6):864-9.

3. Chopra D, Arora P, Khan S, Dwivedi S. Anaphylaxis following intravenous ranitidine: a rare adverse reaction of a common drug. Indian J Pharmacol. 2014;46(2):234-6.

4. Park KH, Pai J, Song DG, Sim DW, Park HJ, Lee JH, et al. Ranitidine-induced anaphylaxis: clinical features, cross-reactivity, and skin testing. ClinExp Allergy. 2016;46(4):631-9.

5. Walker Al, Werfel S, Kick G, Przybilla B. Repeated anaphylactic responses induced by oral challenge with ranitidine. Acta Derm Venereol. 2010;90(2):189.

6. Gomes ER, Demoly P. Epidemiology of hypersensitivity drug reaction. Curr Opin Allerty Clin Immunol. 2005;5(4):309-6.

7. Deva $S$, Jameson M. Histamine type 2 receptor antagonists as adjuvant treatment for resected colorectal cancer. Cochrane Database Syst Rev. 2012;15(8):CD007814.

8. Dhanya NB, Rai R, Srinivas CR. Histamine 2 blocker potentiates the effects of histamine 1 blocker in suppressing histamine-induced wheal. Indian J Dermatol Venereol Leprol. 2008;74(5):475-7.

9. Fedorowicz Z, Zuuren EJ, Hu N. Histamine H2-receptor antagonists for urticaria. Cochrane Database Syst Rev. 2012;14(3):CD008596.

10. Khosla PP, Saha N, Koul A, Chakrabarti A, Sankaranarayanan A, Sharma $P L$. Effects of ranitidine alone and in combination with chlorpheniramine on histamine-induced wheal and flare and psychomotor performance. Indian J Physiol. Pharmacol. 1993;37(2):132-4.

11. Kupczyk M, Kupryś I, Bocheńska-Marciniak M, Górski P, Kuna P. Ranitidine (150 mg daily) inhibits wheal, flare, and itching reactions in skin-prick tests. Allergy Asthma Proc. 2007;28(6):711-5.

12. Phupong V, Hanprasertpong T. Interventions for heartburn in pregnancy. Cochrane Database Syst Rev. 2015;19(9):CD011379. 